\title{
The Global Ocean Biodiversity Initiative: promoting scientific support for global ocean governance
}

David JOHNSON ${ }^{1}$, Christopher BARRIO FROJÁN ${ }^{1}$, Nicholas BAX ${ }^{2}$, Piers DUNSTAN ${ }^{2}$, Skipton WOOLLEY ${ }^{2}$, Pat HALPIN ${ }^{3}$, Daniel DUNN ${ }^{3}$, Carolina HAZIN ${ }^{4}$, Maria DIAS ${ }^{4}$, Tammy DAVIES ${ }^{4}$, Jorge JIMÉNEZ ${ }^{5}$, Erick ROSS $^{5}$, Cindy VAN DOVER ${ }^{4}$, Giuseppe NOTARBARTOLO DI SCIARA ${ }^{6}$, Erich HOYT ${ }^{7}$, Michael J. TETLEY ${ }^{8}$, Vikki GUNN ${ }^{1}$, Henning VON NORDHEIM ${ }^{9}$

${ }^{1}$ Seascape Consultants Ltd, Romsey, United Kingdom

${ }^{2}$ CSIRO Oceans and Atmosphere, Hobart, Tasmania, Australia

${ }^{3}$ Division of Marine Science and Conservation, Nicholas School of the Environment, Duke University, Beaufort, North Carolina, USA

${ }^{4}$ BirdLife International, Cambridge, United Kingdom

${ }^{5}$ Fundación MarViva, San José, Costa Rica

${ }^{6}$ Tethys Research Institute and IUCN Marine Mammal Protected Areas Task Force

${ }^{7}$ Whale and Dolphin Conservation and IUCN Marine Mammal Protected Areas Task Force

${ }^{8}$ IUCN Marine Mammal Protected Areas Task Force

${ }^{9}$ Marine Directorate, German Federal Agency for Nature Conservation, Putbus, Germany

\section{Abstract}

1. Addressing the challenge of protecting biodiversity in the global ocean requires a sound knowledge and understanding of the complex marine environment.

2. Since 2008 the Global Ocean Biodiversity Initiative (GOBI) has been established as a voluntary dedicated group of marine institutions and scientists working to support conservation and protection of marine biodiversity. A focus has been work to support the Convention on Biological Diversity's Ecologically or Biologically Significant Marine Area (EBSA) process. GOBI

This is the author manuscript accepted for publication and has undergone full peer review but has not been through the copyediting, typesetting, pagination and proofreading process, which may lead to differences between this version and the Version of Record. Please cite this article as doi: $10.1002 /$ aqc.3024

This article is protected by copyright. All rights reserved. 
partners have provided expert interpretation of evidence-based information and sought to compile and collate available information.

3. An effective and coherent global network of marine protected areas (MPAs) must include bioregional representative replicates of features and, once described, EBSAs can help focus attention on where and what kind of protective measures may be needed.

4. $\mathrm{GOBI}$ is currently undertaking a five-year programme of research funded by the German International Climate Initiative, working to strengthen baselines and contribute new data to the EBSA and other processes. This involves developing detailed biogeographies for the Pacific and Indian Oceans, assessing the movement of migratory species, advancing understanding of biodiversity at vents and seeps, developing a model governance system for the Costa Rica Thermal Dome, and incorporating Important Bird and Biodiversity Areas and Important Marine Mammal Areas.

5. GOBI has taken initiatives to build on the results of the Census of Marine Life and ensure best available marine biodiversity information is considered by States and intergovernmental organizations. GOBI support for ocean governance including data development and expert consultation will also contribute to the United Nations Decade of Ocean Science for Sustainable Development (2021-2030). Future challenges include capacity building and new approaches to incorporate traditional knowledge.

Key words: biodiversity conservation, EBSAs, GOBI, marine governance, MPA networks

\section{Introduction}

The Convention on Biological Diversity's (CBD) process to describe Ecologically or Biologically Significant Marine Areas (EBSAs) selects areas of the ocean with special importance because they provide, for example, essential habitats, food sources or breeding grounds for particular species. An evolution of thinking as recognized by CBD Parties is set out by Dunn et al. (2014). Critically, in 2008, the Parties to the CBD adopted a set of seven scientific criteria to identify ecologically or biologically significant areas in the open oceans and deep seas (Ardron et al., 2009).

The expert-driven process of assessing potential areas against the seven agreed scientific criteria, through a series of regional workshops, provides a framework to methodically and objectively describe those areas of the ocean that may merit additional protection, and to promote a healthy global marine ecosystem (Bax et al., 2016; Dunn et al., 2014). To date, more than 300 EBSAs have been described around the world. They occur in all regions of the planet from the poles to the 
equator, and in all water depths from the coast to the deep ocean. EBSAs can be found in national waters, span territorial boundaries, lie partially or wholly within areas beyond national jurisdiction, and can often overlap each other.

Established in $2008^{1}$ in response to the need for data and scientific expertise to support the EBSA process, the Global Ocean Biodiversity Initiative (GOBI; www.gobi.org) is an international partnership of institutions and scientists committed to advancing the scientific basis for conserving biological diversity in the marine environment. GOBI has supported the EBSA concept since its inception by: (i) developing background documents laying out how to describe areas relative to the EBSA criteria (Dunn et al., 2014), (ii) developing the first EBSA Repository ${ }^{2}$ prototype, (iii) providing technical support, capacity development and facilitation for all of the 14 regional EBSA workshops to date, (iv) summarizing the history of the EBSA process (Dunn et al., 2014), (v) reviewing the results (Bax et al., 2016; Johnson, Barrio-Froján, et al., 2018), (vi) participating in CBD Expert Workshops, and (vii) presenting at EBSA side events to help explain the process, the data that were used, the results and their potential uses. The GOBI partnership now comprises more than 40 organizations around the world working to generate new information and science to support ecosystem-based management of the marine environment, and area-based management approaches in particular. The intention is to foster adaptive approaches to reduce the rate of biodiversity loss through the application of ecosystem approaches to the management of human activities which can include enhanced resource management and impact assessment, and the establishment of effective areabased conservation measures, including marine spatial planning and networks of MPAs, in national and international waters. GOBI partners engage across all levels of government at international, regional, national and local levels, and use their expertise, knowledge and data to develop and support appropriate tools and methodologies.

While GOBI originated in response to the need to support and inform the CBD EBSA process, the growing results from that process and the expanding network of partners has afforded GOBI the opportunity to broaden the scope of its work. Today, GOBI is committed to supporting the 2030 Agenda for Sustainable Development and in particular SDG $14^{3}$, Aichi Target $11^{4}$ and United Nations

\footnotetext{
${ }^{1}$ As a consequence of promising marine conservation agreements at the Conference of Parties (COP) of the Convention on Biological Diversity (CBD) in Bonn, Germany (CBD COP9, 19-30 May 2008).

${ }^{2}$ The CBD has developed a website giving access to a site map of EBSAs, supporting reports and relevant COP Decisions, known as the EBSA Repository (https://www.cbd.int/ebsa/).

${ }^{3}$ Sustainable Development Goal 14: Conserve and sustainably use the oceans, seas and marine resources for sustainable development.

${ }^{4}$ Aichi Target 11: By 2020, at least 17 per cent of terrestrial and inland water areas and 10 per cent of coastal and marine areas, especially areas of particular importance for biodiversity and ecosystem services, are conserved through effectively and equitably managed, ecologically representative and well-connected systems of protected areas and other effective area-based conservation measures, and integrated into the wider landscape and seascape.
} 
General Assembly (UNGA) resolution 72/249 on the development of an international legally binding instrument under the United Nations Convention on the Law of the Sea (UNCLOS) on the conservation and sustainable use of marine biological diversity of areas beyond national jurisdiction (ABNJ). The data collated by GOBI partners have informed the work of the Convention on Migratory Species $^{5}$ (Kot, Halpin, Cleary, \& Dunn, 2014), the United Nations Educational, Scientific and Cultural Organization (UNESCO) report on expanding the purview of the World Heritage Convention to ABNJ (Freestone, Laffoley, Douvere, \& Badman, 2016), and efforts to create frameworks for the designation of no-mining areas within regional environmental management plans (Dunn, Van Dover et al., 2018). In this context GOBI's role is to provide guidance on how biodiversity data and criteria can be interpreted and applied to inform policy and management.

The collaborative process of acquiring and interpreting information developed through the regional EBSA workshops has also influenced the way that scientists continue to work with GOBI. A characteristic of projects developed under $\mathrm{GOBI}$ and described below is their emphasis on engaging local and regional communities, providing the opportunity for strong ownership of the project outputs. This paper outlines GOBI's most recent work areas and considers GOBI's future agenda and implications for an ongoing broader engagement process.

\section{$2 \mathrm{GOBI}$ efforts to strengthen baselines}

Building on Germany's ongoing support for the GOBI Secretariat, in 2016, GOBI was awarded a grant of $€ 5.2 \mathrm{~m}$ by Germany's International Climate Initiative (IKI $)^{6}$. The funding, effective for a period of five years, is spread across six complementary scientific research topics and includes support for the coordinating GOBI Secretariat. The research is intended to assist States and intergovernmental organizations in determining the strengths, challenges and limitations of available data and in turn, to strengthen EBSA descriptions through the generation and assimilation of new data on key overarching themes. Together, GOBl's efforts combined with those from its peers and counterparts from science, industry, government and civil society, will continue to inform the negotiation of an international legally binding instrument under the UNCLOS on the conservation and sustainable use of marine biological diversity of areas beyond national jurisdiction (ABNJ). Work under the GOBI-IKI programme is undertaken by a subset of international GOBI partners, namely: Australia's national science agency, the Commonwealth Scientific and Industrial Research Organization (CSIRO), the

\footnotetext{
${ }^{5}$ UNEP/CMS/Resolution 11.25 on Advancing Ecological Networks to address the needs of migratory species specifically welcomes the GOBI review of EBSAs and migratory species and Decisions 12.40 and 12.41 adopted Resolutions endorsing IMMAs, recognising IMMA selection and review criteria and collaborative arrangements (UNEP/CMS/COP12/Doc 24.2.1).

${ }^{6}$ URL: http://www.international-climate-initiative.com
} 
Nicholas School of the Environment at Duke University in North Carolina USA, the MarViva Foundation in Costa Rica, BirdLife International headquartered in Cambridge UK, and the Tethys Research Institute based in Milan, Italy. The research and analysis programme carried out by each partner institution is described below.

The team at CSIRO is developing new statistical approaches, combined with expert interpretation, for the bioregionalization of the Indian and south-western Pacific Oceans. Bioregions identified by the process combine the physical and biological variability in the environment at an ocean basin scale and at a province scale into areas that share similar ecological and biological systems that are distinct from areas around them. They build on the best available datasets and existing regionalizations to provide a harmonized product that combines the strengths of many previous endeavours. The exercise is complicated by the three-dimensional nature of the ocean, with most ecological and biological systems displaying strong gradients across the depth range. This means that a map of distinct bioregions at the sea surface could be very different from a map of bioregions in the same area at depth. To identify where the boundaries between bioregions lie on a horizontal plane as well as on a vertical plane - or even to determine whether there is a case for a 'hard' boundary instead of a porous 'soft' boundary between aqueous bioregions - requires not only the best data available, but also a profound understanding of marine ecology and the means to translate every assumption or condition into state-of-the-art mathematical models that are statistically robust. Workshops have been held to engage regional and national experts with available physical oceanographic and biological datasets, and to test the validity of outcomes from the evolving statistical bioregionalization exercises. Eventually, the resultant maps from all these efforts may inform the choice of spatial or temporal management measures on fishing, mining, marine traffic or industrial pollution. They may also be useful for the placement of MPAs to ensure optimum connectivity and representativity of protected features.

Project partners at Duke University are undertaking research on two ground-breaking fronts: one assessing the movement of migratory species across the ocean, the other considering needs to protect biodiversity from serious harm resulting from deep-sea mining. Migratory animals routinely travel vast distances at various stages of their lifecycle and therefore depend on the continued presence of favourable conditions all along their migratory routes to complete their journey and maintain their population. Many other species depend on the predictable passage of migrants to complete their own lifecycle. While numerous studies report on the movements of selected migratory species over discrete periods of time, the current research effort aims to compile all available data across the scientific and grey literature on all marine migratory taxa, creating a database on migratory connectivity with capacity to visualize and model multiple migratory behaviours on a global scale. This tool will provide a way to test how important certain areas of the ocean are for connecting populations (e.g. dispersion bottlenecks or highways) and, in turn, what 
the most effective conservation measures would be to preserve the connectivity between distant yet interdependent ecosystems.

The GOBI effort at Duke University also focuses on several issues relating to the environmental management of mineral exploitation in the deep sea, including: (i) consideration of the potential for loss of biodiversity that might result from mining activities in the deep sea (Niner et al., 2018; Van Dover et al., 2017), (ii) development of a framework for science-based design and design assessment of networks of no-mine areas (so-called Areas of Particular Environmental Interest or APEIs) on midocean ridges (Dunn et al., 2018) in support of environmental management efforts of the International Seabed Authority (ISA), which has the exclusive mandate to regulate access to the area and its resources consistent with UNCLOS, and (iii) deliberation on the need for protection of active hydrothermal vent ecosystems (Van Dover et al., 2018) to inform regional environmental management plans for polymetallic sulphide deposits. These activities are intended to contribute to protection of the marine environment and strategies for sustainable development of seabed mining.

The MarViva Foundation in Costa Rica is the self-appointed guardian of the Costa Rica Thermal Dome. The Dome is an oceanographic feature located off the coast of Central America that is created by seasonal changes in interconnected coastal jet streams, eddies and currents (Jiménez, 2016). The Dome is important for a variety of organisms, especially large pelagic species. Three species of cetaceans are abundant in the Dome: the striped dolphin (Stenella coeruleoalba), the short-beaked common dolphin (Delphinus delphis) and the blue whale (Balaenoptera musculus); 14 other species show distributions that extend into the Dome (Fiedler, Redfern, \& Balance, 2017). Marine turtles have a direct link to the Dome; two olive Ridley turtles (Lepidochelys olivacea) tagged in the region stayed in its area of influence for over four months (Johnson, Ross Salazar, et al., 2018), while the most important nesting beach for leatherback turtle (Dermochelys coriacea) is also within the Dome's area of influence, as adult females head towards feeding grounds in the Southern hemisphere through its waters (Shillinger et al., 2008). Large offshore pelagic features such as the Dome are worthy of extra consideration and enhanced efforts to maintain their healthy functions (Johnson, Ross Salazar, et al., 2018). The Dome has a significant impact on the economies of nearby countries. Maritime traffic is intense in the region, with 14,000 deep-draft ships carrying $50 \%$ of the world's maritime cargo using the Panama Canal (COCATRAM, 2013; Forbes, 2014), of which a significant percentage use routes that cross the Dome (Jiménez, 2016). The Dome's rich waters supply fisheries in the region; catches of up to $26 \mathrm{t} /$ day of yellowfin tuna have been reported (Ichii et al., 2002), while yellowfin caught in the eastern tropical Pacific represent $25 \%$ of the world catch for the species. The sports fishing industry generates more than US\$599 million and 63,000 direct and indirect jobs in Costa Rica (Yong-Chacón et al., 2010), while in Panama the industry represents US\$170 million and 86,000 tourists (Southwick, Nelson, Lachman, \& Dreyfus, 2013), and in Guatemala it is a US\$25 million industry (Villagrán, 2015). The MarViva Foundation is on a mission 
to raise awareness of the benefits derived from the Dome at a Central American scale, and to promote ecologically responsible behaviour among the citizens of Costa Rica. The evidence gathered will strengthen the case for exceptional locations in ABNJ such as the Dome to be considered for World Heritage status, as well as highlight the need for a functioning Regional Seas Convention in this region (Johnson, Ross Salazar, et al., 2018).

BirdLife International's work within the GOBI portfolio concentrates on its ongoing efforts in identifying the most important marine bird and biodiversity areas (marine IBAs) and advocating for their effective protection (Dias et al., 2017; Donald et al., in press; Lascelles et al., 2016), with a special focus on the Indian Ocean. Data uploaded to the Seabird Tracking Database ${ }^{7}$ by BirdLife International's collaborators (contributed by almost 200 researchers worldwide) are combined and analysed to find the marine areas more intensively used by seabirds for foraging and travelling during different stages of their annual cycle (breeding, migration, winter periods; Dias et al., 2017; Lascelles et al., 2016; Soanes et al., 2016). Understanding the role that seabirds play in the oceanic ecosystem, as well as how the ecosystem itself drives bird behaviour, allows for the modelling of seabird distribution under projected future climatic scenarios (e.g. Krüger et al., 2018). Since seabirds are a more visible element of the marine environment, their state and fate serve as a weathervane to assess the effectiveness of global conservation efforts on all marine biodiversity (e.g. Ronconi, Lascelles, Longham, Reid, \& Oro, 2012). Equally, focusing current conservation efforts on areas already known to be important for the persistence of seabirds is an easy first step towards the protection of multiple aspects of the ocean that underpin and promote biodiversity and ecosystem function. Marine IBAs identified by BirdLife International have contributed significantly to the description of EBSAs all over the world (e.g. the Clipperton Fracture Zone Petrel Foraging Area IBA and EBSA in the equatorial Pacific Ocean, or the Indian Ocean Western 31 Marine IBA also known as the Arabian Basin EBSA), as well as informed MPAs in various countries (Waliczky et al., in press). Marine IBAs have also been used to support national governments' efforts to meet international targets (e.g. baseline data for Aichi Target 11 'areas of particular importance for biodiversity'). Further work will augment and strengthen the network of identified areas that are significant for the continued persistence of seabirds, as well as of all the resources they - and we depend upon.

In a similar way to seabirds, marine mammals are a conspicuous element of marine biodiversity because of their status as umbrella and indicator species, combined with their need to breathe air, which brings them to the surface on a regular basis. This makes them easier subjects to study and monitor compared to many other marine species (Hoyt, 2011). Marine mammals are diverse in their ecological preferences and, while some species occupy vast expanses of the ocean during their

\footnotetext{
${ }^{7}$ URL: http://www.seabirdtracking.org
} 
lifetimes (e.g. sperm, humpback, killer whales), others prefer a narrower range of environmental conditions (e.g. narwhal, dugong, river dolphins). As such, efforts to protect and conserve marine mammals have ramifications that affect almost every other aspect of biodiversity in the ocean. Despite their size and appeal, relatively little is known about their precise distribution, migratory habits and habitat needs (Hoyt, 2011). Supported by GOBI, the IUCN Marine Mammal Protected Areas Task Force focuses on identifying and protecting marine mammal habitats, and is attempting to produce a body of knowledge to start to address the gaps. Between 2016-2021, a series of regional expert workshops are being held across the Indian and Pacific Oceans, in which local experts are invited to share their knowledge and work towards the identification of areas of interest (Aol) that the workshop then selects from to make candidate important marine mammal areas (IMMAs). IMMAs are defined as discrete portions of habitat important to marine mammal species, that have the potential to be delineated and managed for conservation (Notarbartolo di Sciara et al., 2016). IMMAs are identified on a regional basis and must fulfil one or more criteria (species or population vulnerability; distribution and abundance, including small and resident populations and aggregations; key life cycle activities, including reproductive areas, feeding areas and migration routes; and special attributes, including distinctiveness and diversity) (Tetley et al., 2016). All candidate IMMAs are examined by an independent review panel, and those not approved remain as Aol. Information gathered through this formal process will serve to strengthen existing EBSA descriptions where they overlap, as well as provide new evidence in support of future spatial and other conservation efforts, in ABNJ.

The IMMA work is of direct relevance to both Convention on Migratory Species (CMS) and CBD. The IUCN Marine Mammal Protected Area Task Force efforts complement the EBSA workshops, but there are subtle differences (see Table 1). IMMA workshops have already taken place for the Mediterranean (2016), Pacific Islands (2017) and the North-East Indian Ocean and South-East Asian Seas (2018). The Task Force selects workshop participants on the basis of their publication record and ongoing fieldwork in the region. The intention is to build an active community of expertise involving MPA managers, promoting knowledge sharing and addressing threats to discrete subpopulations of marine mammals, some of which are highly migratory. IMMAs have the potential to influence management of existing MPAs by, for example, prompting proposals for zoning, providing evidence to support use restrictions, and/or focussing research priorities. Awareness of IMMAs, like EBSAs, may prompt additional considerations for Environmental Impact Assessments (e.g., measures to mitigate noise disturbance), additional monitoring and surveillance, and additional considerations when developing or revising marine spatial plans. 


\section{$3 \mathrm{GOBI}$ into the future}

During a dedicated workshop at IMPAC4, a group of delegates reflected on the EBSA process and GOBI's contribution to provide data and methodologies. At the workshop, data layers were available and cross-references made to the World Database on Protected Areas. EBSAs are not MPAs; they provide a scientific context for the consideration of protective measures. However, the purpose of the exercise was to consider the utility of the EBSA description for designating an MPA using a series of prompt questions as follows:

- What are the opportunities for developing an MPA proposal in this context? What might it focus on? Water column and/or sea floor? All or part of the feature? Buffer zone required? Linking to a network?

— What are the challenges?

- Which aspects of the EBSA description are most useful for the development of an MPA or other area-based management tools? How does this work with the different IUCN MPA categories (restricted use to multiple use)?

- What data are critical?

- What action can be taken where data are poor?

This exercise highlighted the value of the EBSA process to help consolidate and share data and marine surveys. A key scientific challenge in the marine environment is that data are too fragmented. Spatial data have different reference systems (e.g. projections, datum) and different levels of quality (e.g. accuracy, completeness). Coverage of biological data is particularly influenced by the method of sampling, and records held in the Ocean Biogeographic Information System (OBIS) ${ }^{8}$ can be strengthened by working with surrogates when no/little biological data are available (e.g. bathymetry, water temperature, currents, primary productivity, slope, ruggedness). The outputs from GOBI's research programme will help by refining marine habitat classifications, evaluating ecological coherence and deciding on indicators that reflect the integrity of ecosystems.

An area described as an EBSA is not automatically subject to any specific management measures or restriction of activities, but is an indispensable starting point for a scientific and technical description and recognition of an area's biological or ecological significance. The information used to describe EBSAs is also highly valuable for conservation and management, for example, by supporting the case

\footnotetext{
${ }^{8}$ URL: http://www.iobis.org/
} 
for area-based management tools including MPAs. Annex II of CBD Decision IX/20 (CBD, 2008) sets out scientific guidance for selecting areas to establish a representative network of MPAs, including in open ocean waters and deep-sea habitats. Requisite network properties and components (i.e. potential for representativity, connectivity, replicated ecological features and adequate/viable sites) are elements that GOBI-IKI work programme is addressing. Von Nordheim (2018) highlighted the compatibility of EBSA criteria and the detailed MPA selection criteria adopted by the Helsinki and the OSPAR Commissions, noting also that the conservation objectives of MPAs usually address the protection, conservation and/or restoration of site-specific values and features.

Voluntary practical studies and options for further enhancing scientific methodologies and approaches for the scientific and technical EBSA exercises were welcomed by CBD COP13, which established objectives for an expert workshop to develop options for modifying the description of existing EBSAs, for describing new areas, and for strengthening the scientific credibility and transparency of this process (CBD, 2018). This workshop took place in Berlin (5-8 December 2017), providing an opportunity for participants to exchange information on examples and lessons learned from relevant global, regional and national processes. Experiences shared at the workshop, including examples of new data and new methodologies to assess the data, confirmed there is a need to revisit the regions in which EBSAs have been described since 2011, both to update descriptions of existing EBSAs and to consider information regarding potential new areas that may meet the EBSA criteria. The Berlin workshop specifically noted that the regional EBSA process provides an important baseline for long-term monitoring and systematic assessment. The need for a systematic assessment of the representation of biogeographic and taxonomic features in areas meeting the EBSA criteria was identified as a priority next step for future assessment and monitoring. The outcomes of these intercessional scientific gap analyses would be evaluated to support the prioritization for new regional/sub-regional/inter-regional workshops and/or thematic workshops. GOBI partners are beginning work on this process to help inform an initial assessment of the global collection of EBSAs. In addition, participants noted a need to explore the possible application of an 'EBSAs at risk' monitoring concept, drawing on the experience from other relevant instruments, to identify EBSAs that have undergone significant change since they were described.

Additionally, in line with GOBI's research efforts, there was recognition that there are many cases where the features meeting the EBSA criteria overlap either the exclusive economic zones (EEZs) of two or more countries, or extend into marine ABNJ, or both. In these cases, national EBSA processes within individual EEZs would not be sufficient to describe transboundary ecological features meeting the EBSA criteria or for keeping the EBSA description scientifically sound and up to date. GOBI is working with regional partners, such as the Benguela Current Commission, to develop options for dealing with such situations. Similarly, there are mechanisms for input of traditional/local knowledge, but there is often limited input of these knowledge systems in the description of areas 
meeting the EBSA criteria. GOBI will seek to better understand and incorporate traditional knowledge systems into regional biogeographies and specific efforts such as identifying IMMAs. There is also a need for more organized capacity building before and after regional EBSA workshops, and awareness-building for other ministries and stakeholders that need to cooperate in marine spatial planning and adopting enhanced conservation and management measures for EBSAs. This has been a role for the CBD's Sustainable Ocean Initiative ${ }^{9}$, for example, most recently delivering a national EBSA capacity building workshop in Cameroon (17-19 January 2018). In the case of Cameroon, many of the coastal marine ecosystems are river-driven with relatively low productivity, low salinity and high turbidity supporting important mangrove forests, hence a need to build links with the Council of Ministers of the Central African Forest Commission as well as involving those directly responsible for the marine environment and fisheries. For existing EBSAs, reasons for potential modification have been suggested (such as changes to IUCN Red List Species, new information, or corrections to errors), together with considerations on actors who can propose modifications and options for the differentiation between a significant modification and a minor modification.

GOBI experts have expressed significant support for regional EBSA workshops to continue to be held, notwithstanding the potential value of other types of workshops (thematic, global, cross-regional), and for opportunities to incorporate traditional knowledge. For new areas meeting the EBSA criteria different procedural options for actors to decide on the need for description of new areas were proposed, together with recognition of capacity building needs. The 2017 CBD EBSA workshop in Berlin also made suggestions to restructure the EBSA website, including provision of information on business of the EBSA Informal Advisory Group (agreed by CBD COP13 (CBD, 2016)) and indicative types of information that should be in the EBSA information-sharing mechanism. GOBI, with its research strands that will develop and refine methodologies, harness new data and make connections between ecosystem components, has a key role to play in persuading decision-makers to introduce appropriate conservation measures.

\section{Conclusion}

At its inception, GOBI's role was working towards High Seas conservation and justifying why the deep sea and open ocean are important. Adoption by CBD Parties of the Azores Scientific Criteria and Guidance for identifying EBSAs in 2008 initiated efforts by GOBI to promote scientific methods and techniques relevant to each criterion. GOBI's role became central to assisting with applying the criteria for benthic and pelagic systems in all marine waters. In data-deficient regions this included

\footnotetext{
${ }^{9}$ URL: http://www.cbd.int/soi/
} 
predictive modelling of the occurrence, abundance, movement and range of species and ecosystems. GOBI developed practical illustrations of how CBD criteria can be applied and connected scientific experts and groups to cooperate with governments, international and nongovernmental organizations. This work has continued and been complemented by generating new knowledge, in particular mapping species, habitats and ecosystems and demonstrating connectivity. The original vision of $\mathrm{GOBI}$ remains relevant, but its role has grown and matured as ocean governance has gained prominence and importance on global agendas over the past decade. In future, the emphasis is likely to focus on forging partnerships, building capacity and maximizing the utility of EBSA information, recognizing that area-based management approaches can address a multitude of threats. Implications for an on-going broader GOBI engagement process include:

- The need to revisit - applied science is not a one step process but an iterative process that supports improved knowledge for all participants and builds enduring relationships that have importance beyond any workshop or topic of the workshop. Successful engagement by GOBI partners provides an important pointer for future capacity development activities requested under most international policy initiatives and the UN Decade of Ocean Science.

- The recognition that the ocean does not respect boundaries and that therefore capacity development and science in general needs to take on a regional approach while still remaining relevant to the individual jurisdiction that will act on it. The Large Marine Ecosystem (LME) programme offers an example of this regional approach with its Transboundary Diagnostic Analysis, but has not done so well on national uptake. Adapting a regional collaborative workshop approach may provide a way to improve this (Vousden \& Scott, 2017).

- Incorporating traditional knowledge, accepting that many indigenous groups may not be willing to travel outside their country and may not feel competent to talk generally about issues and values outside their own locality. New approaches are needed where the researchers visit the knowledge holders rather than the other way around.

- Need for capacity building to enable practitioners to participate fully in workshops. If all countries are to participate fully and confidently in national and international negotiations, time will have to be spent raising their knowledge and understanding.

With the expertise of 10 years of successful and engaged global cooperation, GOBI partners will continue to play a key role in presenting science-based advice and support for marine biodiversity conservation to bodies including CBD, CMS, IOC, GOOS, GEO BON, RFMOs, ISA, IMO, IPCC, IPBES, WOA 2, the BBNJ process under UNCLOS, regional seas conventions and national governments. Such work makes significant progress towards the ultimate goal: a truly global network of well- 
connected ecologically and biologically important marine areas protected by appropriate conservation measures.

\section{Acknowledgements}

GOBI is supported by the International Climate Initiative (IKI). The German Federal Ministry for the Environment, Nature Conservation and Nuclear Safety (BMU) supports this initiative on the basis of a decision adopted by the German Bundestag. The authors are grateful for the constructive feedback from reviewers that helped focus and improve the manuscript.

\section{References}

Ardron, G., Dunn, D., Corrigan, C., Gjerde, K., Halpin, P., Rice, J., ... Vierros, M. (2009). Defining ecologically or biologically significant areas in the open oceans and deep seas: Analysis, tools, resources and illustrations. Report of the Convention on Biological Diversity expert workshop on scientific and technical guidance on the use of biogeographic classification systems and identification of marine areas beyond national jurisdiction in need of protection, Ottowa, CA, 29 September-2 October 2009, 73 pp.

Bax, N.J., Cleary, J., Donnelly, B., Dunn, D. C., Dunstan, P.K., Fuller, M., \& Halpin, P.N. (2016). Results of efforts by the Convention on Biological Diversity to describe ecologically or biologically significant marine areas. Conservation Biology, 30, 571-581.

CBD. (2008). Decision adopted by the Conference of the Parties to the Convention on Biological Diversity at its ninth meeting, Bonn, 19-30 May 2008. UNEP/CBD/COP/DEC/IX/20 https://www.cbd.int/doc/decisions/cop-09/cop-09-dec-20-en.pdf

CBD. (2016). Decision adopted by the Conference of the Parties to the Convention on Biological Diversity at its thirteenth meeting, Cancun, 4-17 December 2016. UNEP/CBD/COP/DEC/XIII/12. https://www.cbd.int/doc/decisions/cop-13/cop-13-dec-12-en.pdf

CBD. (2018). Report of the Expert Workshop to develop options for modifying the description of ecologically or biologically significant marine areas, for describing new areas, and for strengthening the scientific credibility and transparency of this process. Berlin, 5-8 December 2017CBD/EBSA/EM/2017/1/3. https://www.cbd.int/doc/c/6ac0/03a0/d4179dfc152efaeefd81d35e/ebsa-em-2017-01-03-en.pdf 
COCATRAM. (2013). Origen y Destino de la Carga en Centroamerica. 39 pp.

http://issuu.com/cocatram/docs/origen_y_destino_de_la_carga_mariti/0

Dias, M.P., Oppel, S., Bond, A.L., Carneiro, A.P.B., Cuthbert, R.J., González-Solís, J., ...Ryan, P.G. (2017). Using globally threatened pelagic birds to identify priority sites for marine conservation in the South Atlantic Ocean. Biological Conservation, 211, 76-84.

Donald, P.F., Fishpool, L.D.C., Ajagbe, A., Bennun, L.A., Bunting, G., Burfield, I., ... Wege, D. (in press). Important Bird and Biodiversity Areas (IBAs): The development and characteristics of a global inventory of key sites for biodiversity. Bird Conservation International.

Dunn, D.C., Van Dover, C.L., Etter, R.J., Smith, C.R., Levin, L.A., Morato, T., ... SEMPIA Workshop Participants. (2018). A strategy for the conservation of biodiversity on mid-ocean ridges from deepsea mining. Science Advances, 4, eaar4313.

Dunn, D.C., Ardron, J., Bax, N., Bernal, P., Cleary, J., Cresswell, I., ... Halpin, P.N. (2014). The Convention on Biological Diversity's Ecologically or Biologically Significant Areas: Origins, development, and current status. Marine Polic,y 49, 137-145.

Fiedler, P.C., Redfern, J.V., \& Balance, L.T. (2017). Oceanography and cetaceans of the Costa Rica Dome Region. NOAA Technical Memorandum NMFS. National Oceanographic and Atmospheric Administration. Vol. NOAA-TM-NMFS-SWFSC-590: 35pp.

Forbes. (2014). Centroamérica, el próximo nodo logístico mundial, Oct, 2014. México. http://www.forbes.com.mx/centroamerica-el-proximo-nodo-logistico-mundial/

Freestone, D., Laffoley, D., Douvere, F., \& Badman T. (2016). World Heritage in the High Seas: An Idea whose Time Has Come. World Heritage Reports 44. July 2016. 79pp.

Hoyt, E. (2011). Marine protected areas for whales, dolphins and porpoises. A world handbook for cetacean habitat conservation and planning. Second Edition. Earthscan, London \& New York. 464 pp.

Ichii, T., Mahapatra, K., Watanabe, T., Yatsu, A., Inagake, D., \& Okada, Y. (2002). Occurrence of jumbo flying squid Dosidicus gigas aggregations associated with the countercurrent ridge off the Costa Rica Dome during 1997 El Niño and 1999 La Niña. Marine Ecology Progress Series, 231, 151166.

Jiménez, J.A. (2016). El Domo Térmico de Costa Rica: Un oasis de productividad frente a las costas del Pacífico Centroaméricano. Fundación MarViva. San José, Costa Rica. 
Johnson, D.E., Barrio Froján, C., Turner, P.J., Weaver, P., Gunn, V., Dunn, D.C., ...Dunstan, P.K. (2008). Reviewing the EBSA process: Improving on success. Marine Polic, y 88, 75-85.

Johnson, D.E., Ross Salazar, E., Gallagher, A., Rees, A., Sheridan Rodriguez, C., Cambronero Solano, S., ... Barrio Froján, C. (2018). Preventing plastics pervading an oceanic oasis: Building the case for the Costa Rica Thermal Dome to become a World Heritage site in ABNJ. Marine Policy doi.org/10.1016/j.marpol.2018.02.022

Kot, C.Y., Halpin, P., Cleary, J., \& Dunn, D. (2014). A review of marine migratory species and the information used to describe EBSAS. Marine Geospatial Ecology Lab, Duke University for the Convention on Migratory Species. http://www.cms.int/sites/default/files/document/COP11_Inf_23_EBSA_final_report.pdf

Krüger, L., Ramos, J., Xavier, J., Grémillet, D., González-Solís, J., Phillips, R., ... Paiva, V. (2018). Projected distributions of Southern Ocean albatrosses, petrels and fisheries as a consequence of climatic change. Ecography ,41, 195-208.

Lascelles, B., Taylor, P., Miller, M., Dias, M.P., Oppel, S., Torres, L., ... Small, C. (2016). Applying global criteria to tracking data to define important areas for marine conservation. Diversity and Distributions, 22, 422-431.

Niner, H.J., Ardron, J.A., Escobar, E.G., Gianni, M., Jaeckel, A., Jones, D.O.B, ... Gjerde, K.M. (2018). Deep-sea mining with no net loss of biodiversity - an impossible aim. Frontiers in Marine Science, 5, 53. doi:10.3389/fmars.2018.00053

Notarbartolo di Sciara, G., Hoyt, E., Reeves, R.R., Ardron, J., Marsh, H., Vongraven, D., \& Barr, B. (2016). Place-based approaches to marine mammal conservation. Aquatic Conservation: Marine and Freshwater Ecosystems, 26, Suppl. 2, 85-100.

Ronconi, R., Lascelles, B. Longham, G.M., Reid, J. B., \& Oro, D. (2012). The role of seabirds in Marine Protected Area identification, delineation, and monitoring: Introduction and synthesis. Biological Conservation ,156, 1-4 .

Shillinger, G.L. Palacios, D.M., Bailey, H., Bograd, S.J., Swithenbank, A.M., Gaspar, P., ... Piedra, R. (2008). Persistent leatherback turtle migrations present opportunities for conservation. PLoS Biology, 6, e171.

Soanes, L.M., Bright J.A., Carter, D., Dias, M.P., Fleming, T., Gumbs, K., ... Green, J.A. (2016). Important foraging areas of seabirds from Anguilla, Caribbean: Implications for marine spatial planning. Marine Polic, y 70, 85-92. 
Southwick, R., Nelson, R. Lachman, R., \& Dreyfus, J. (2013). Sportfishing in Panama: Size, Economic Impacts and Market Potential. Produced for The Billfish Foundation. February, 2013.

Tetley, M.J., Hoyt, E., Notarbartolo di Sciara, G., Ardron, J., Kaschner, K., Panigada, S., ...Fernandez, M. (2016). Initial guidance of the use of selection criteria for the identification of Important Marine Mammal Areas (IMMAs). IUCN Marine Mammal Protected Area Task Force. 60 pp.

Van Dover, C.L., Ardron, J.A., Escobar, E., Gianni, M., Gjerde, K.M., Jaeckel, A., ... Weaver, P.P.E. (2017). Biodiversity loss from deep-sea mining. Nature Geoscience, 10, 464-465.

Van Dover, C.L., Arnaud-Haond, S., Gianni, M., Helmreich, S., Huber, J.A., Jaeckel, A.L., ... Yamamoto, $\mathrm{H}$. (2018). Scientific rationale and international obligations for protection of active hydrothermal vent ecosystems from deep-sea mining. Marine Policy, 90, 20-28.

Villagrán, G. (2015). Guatemala, con el reservorio más grande de pez vela. Diario de Centro América. http://www.dca.gob.gt/index.php/nacional/item/25847-guatemala-con-el-reservoriom\%C3\%A1s-grande-de-pez-vela.

Von Nordheim, H. (2018). Marine Protected Areas: Global Framework, Regional MPA networks and a National Example. In Salomon, M. and Markus, T. (eds) Handbook on Marine Environmental Protection, Chapter 46, pp. 871-889, Springer International Publishing

Vousden, D.H., \& Scott, L. (2017). Large Marine Ecosystems and Sustainable Development: A review of strategic management processes and goals [Internet]. New York: United Nations Development Program

Waliczky, Z., Fishpool, L.D.C, Butchart, S.H.M., Thomas, D., Heath, M., Hazin, C., ... Allinson, T. (in press). Important Bird and Biodiversity Areas (IBAs): The impact of IBAs on conservation policy, advocacy and action. Bird Conservation International

Yong-Chacón, M., Gutiérrez-Li, A., Fernández-García, C., Lucke-Bolaños, R., Rojas, F., \& González, G. (2010). Informe final: un análisis de la contribución económica de la pesca deportiva y comercial a la economía de Costa Rica. Instituto de Investigaciones en Ciencias Económicas de la Universidad de Costa Rica bajo el patrocinio de The Billfish Foundation. San José, Costa Rica: 166pp.

\section{Tables}

Table 1: Contrasting and comparing EBSA and IMMA processes.

\begin{tabular}{|l|l|l}
\hline Issue & EBSAs & IMMAs \\
\hline
\end{tabular}

This article is protected by copyright. All rights reserved. 


\begin{tabular}{|c|c|c|}
\hline Issue & EBSAs & IMMAs \\
\hline $\begin{array}{l}\text { Region boundary } \\
\text { selection }\end{array}$ & $\begin{array}{l}\text { At the workshop by consensus, factoring in other } \\
\text { multilateral environmental agreements and previous } \\
\text { EBSA workshops }\end{array}$ & $\begin{array}{l}\text { Presented by IMMA coordinator based on IUCN marine } \\
\text { region combination, and representation } \\
\text { Sub-regions using Longhurst Provinces, MEOW and } \\
\text { LMEs }\end{array}$ \\
\hline $\begin{array}{l}\text { Selection of } \\
\text { participants }\end{array}$ & $\begin{array}{l}\text { Nominated by Parties and organisations (many with } \\
\text { an agenda and data restrictions) }\end{array}$ & $\begin{array}{l}\text { Task Force nominees. Prep. group. Scientific experts } \\
\text { invited on the basis of publication and reputation and } \\
\text { work in the field. Snowball }\end{array}$ \\
\hline $\begin{array}{l}\text { Jurisdictional } \\
\text { restrictions }\end{array}$ & $\begin{array}{l}\text { Parties may opt to withdraw their EEZ from the } \\
\text { process }\end{array}$ & None (but desire to name range States at later stage) \\
\hline $\begin{array}{l}\text { Freshwater/saltwater } \\
\text { (landward boundary) }\end{array}$ & $\begin{array}{l}\text { Case by case basis - mangrove, saline lagoons and } \\
\text { saltmarsh examples included }\end{array}$ & $\begin{array}{l}\text { Some species included with transboundary tolerance } \\
\text { e.g. River Dolphins (avoid freshwater dominated, but } \\
\text { included marine influenced transition zones) }\end{array}$ \\
\hline Confidence in data & $\begin{array}{l}\text { Highlighted by technical team } \\
\text { Generally accepted as weaker in ABNJ and biological } \\
\text { data is poorer }\end{array}$ & $\begin{array}{l}\text { Expert community driven guidance is given to } \\
\text { participants but can be qualified by IMMA Coordinator }\end{array}$ \\
\hline Recognition of gaps & Section in each EBSA report & Discussion. Flag problem in ABNJ \\
\hline Application of criteria & $\begin{array}{l}\text { Criteria ranked, justification and supporting evidence } \\
\text { with maps/photos }\end{array}$ & $\begin{array}{l}\text { Justification and supporting evidence with } \\
\text { maps/photos, species lists }\end{array}$ \\
\hline Polygons & $\begin{array}{l}\text { Delimitation achieved at the workshop with technical } \\
\text { team support }\end{array}$ & $\begin{array}{l}\text { SeaSketch and QGIS available before the workshop } \\
\text { with additional support during the workshop }\end{array}$ \\
\hline Further classification & $\begin{array}{l}\text { Four emerging categories to help with later } \\
\text { interpretation when considering potential threats } \\
\text { and management measures }\end{array}$ & Possible future consideration \\
\hline Traditional knowledge & $\begin{array}{l}\text { Encouragement to factor traditional knowledge but } \\
\text { limited to date }\end{array}$ & $\begin{array}{l}\text { Ground up expert knowledge from scientists in } \\
\text { developing countries but yet to factor traditional } \\
\text { knowledge }\end{array}$ \\
\hline Point of contact & $\begin{array}{l}\text { Collective workshop responsibility? SCBD? Technical } \\
\text { teams? }\end{array}$ & $\begin{array}{l}\text { Named originator for each IMMA and voluntary } \\
\text { regional coordinators }\end{array}$ \\
\hline Validation of results & $\begin{array}{l}\text { Workshop regarded as peer review. CBD SBSTTA } \\
\text { scrutiny and COP }\end{array}$ & Candidate IMMAs considered by review panel \\
\hline $\begin{array}{l}\text { Availability and } \\
\text { outreach }\end{array}$ & $\begin{array}{l}\text { EBSA Repository (open access but work is needed to } \\
\text { improve utility - no terms and conditions on } \\
\text { metadata, currently in default of accepted data } \\
\text { handling standards), EBSAs communicated to UNGA }\end{array}$ & $\begin{array}{l}\text { IMMA e-ATLAS (open access but IMMA boundary must } \\
\text { be requested to conform with user license and } \\
\text { metadata WCMC standard) }\end{array}$ \\
\hline
\end{tabular}




\section{University Library}

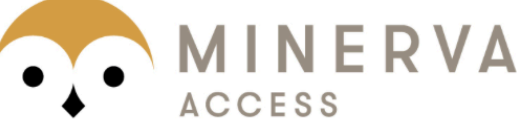

A gateway to Melbourne's research publications

Minerva Access is the Institutional Repository of The University of Melbourne

\section{Author/s:}

Johnson, D;Barrio Froján, C;Bax, N;Dunstan, P;Woolley, S;Halpin, P;Dunn, D;Hazin, C;Dias, M;Davies, T;Jiménez, J;Ross, E;Van Dover, C;Notarbartolo Di Sciara, G;Hoyt, E;Tetley, MJ;Gunn, V;Von Nordheim, H

Title:

The Global Ocean Biodiversity Initiative: Promoting scientific support for global ocean governance

Date:

2019-10-01

\section{Citation:}

Johnson, D., Barrio Froján, C., Bax, N., Dunstan, P., Woolley, S., Halpin, P., Dunn, D., Hazin, C., Dias, M., Davies, T., Jiménez, J., Ross, E., Van Dover, C., Notarbartolo Di Sciara, G., Hoyt, E., Tetley, M. J., Gunn, V. \& Von Nordheim, H. (2019). The Global Ocean Biodiversity Initiative: Promoting scientific support for global ocean governance. Aquatic Conservation: Marine and Freshwater Ecosystems, 29 (S2), pp.162-169. https://doi.org/10.1002/aqc.3024.

Persistent Link:

http://hdl.handle.net/11343/286459 